\title{
THE NECESSITY OF LEGAL TYPOLOGIES IN CRISIS AND EMERGENCY ${ }^{1}$
}

\begin{abstract}
Legal analysis necessarily uses concepts, distinctions and typologies. These tools suffer challenges when the object of analysis or application is a crisis or emergency. The article looks into two examples of legal typologies of emergencies in the works of Gross and Ní Aiolaín and Agamben respectively. Based on this four levels of analysis for legal responses to emergencies is proposed: 1) explicit descriptions of actions by actors themselves, 2) positivist legal categories available in the context, 3) meta/comparative categories, and 4) philosophical/ontological concepts and categories that question or inquire into all the previous categories. The article concludes by discussing how these levels of analysis overlaps, merge and needs to be combined in order to grasp the complex phenomena of law in crisis.
\end{abstract}

Keywords: exception, emergency, crisis, legal concepts, typology.

\section{KONIECZNOŚĆ TYPOLOGII PRAWNICZYCH W KRYZYSIE I SYTUACJI NADZWYCZAJNEJ}

Streszczenie. Analiza prawnicza z konieczności posługuje się pojęciami, rozróżnieniami i typologiami. Narzędzia te napotykają na trudności, gdy przedmiotem analizy lub zastosowania jest kryzys lub sytuacja nadzwyczajna. Artykuł analizuje dwa przykłady typologii prawniczych sytuacji kryzysowych w pracach Grossa i Ní Aiolaín oraz Agambena w ujęciu respektywnym. Na tej podstawie proponuje się cztery poziomy prawniczej analizy odpowiedzi na sytuacje kryzysowe: 1) wyraźne opisy działań samych aktorów, 2) pozytywistyczne kategorie prawne dostępne w danym kontekście, 3) kategorie meta/porównawcze oraz 4) filozoficzne/ontologiczne koncepcje i kategorie, które kwestionują lub badają wszystkie poprzednie kategorie. Artykuł kończy się dyskusją na temat tego, w jaki sposób te poziomy analizy nakładają się na siebie, przenikają i muszą być połączone, aby uchwycić złożone zjawiska prawa w kryzysie.

Słowa kluczowe: wyjątek, sytuacja nadzwyczajna, kryzys, pojęcia prawnicze, typologia.

*University of Gothenburg; tormod.otter.johansen@law.gu.se

${ }^{1}$ I would like to thank Erik Björling, Cosmin Cercel, Gian Giacomo Fusco, Sari Kouvo, Alexandra Mercescu, Rafał Mańko, and Przemysław Tacik, for giving valuable critical comments on earlier drafts as well as the two anonymous reviewers for their valuable suggestions. 


\section{INTRODUCTION}

Jurists approach the world armed with the ability to distinguish, define and conceptualise every phenomenon. But what do we do when faced with events that shake the very foundations of our normal mode of proceeding? Extreme weather events and pandemics, social unrest and political breakdown, hybrid warfare and terrorism - our time is inundated with threats and crises that stretch the ability of ordinary legal structures to cope. When coordinates of normality are disturbed, we might be heading in a wrong direction when using a map made for calmer times.

We need to either use concepts already at hand or reach for new distinctions by producing new categories and typologies. Concepts such as emergency powers, state of exception, sovereign prerogative, martial law, etc. can be used. Still, a concerning worry might creep up on us - even the legal concepts made for exceptional times might be unsuitable or lacking in explanatory and legitimising force. It has even been argued that we live in a time of the permanent state of exception, where the exception has merged with the rule - what use can we have of concepts and typologies of legal responses at all in such a time?

Are they helpful or do we risk acting as naïve Linneans when we distinguish between this and that emergency, or this and that response? Neither actual crises nor legal responses exist out there like flowers and plants. Perhaps the construction of more or less elaborate typologies risks acting as a veil, making it harder to distinguish the reality of emergencies and responses to them. This text will make a tentative inquiry into the usefulness and risks of typologies of legal emergency and crisis responses. A four-level hierarchy of analysis will be presented and related to the epistemological approach, role and loyalty of the jurist. As a conclusion I will argue that we might not and should not escape typologies as jurists, but we would do well to reconsider our approach toward them. We must distinguish different levels of conceptual analysis, and be aware how we use them. I will base my suggestion on a reading of two books on law and crisis (Agamben 2005; Gross, Ní Aoláin 2006).

\section{CONCEPTUAL APPROACH}

Approaching a legal subject, problem or in general a phenomenon always requires a certain conceptual frame. For trained jurists this can take the form of a system, a set of distinctions between objects, concepts and their interrelations. This is both logically necessary and empirically certain. There is no "pure" or unstructured way to approach legal problem or phenomena. This is also the approach that legal analysis and legal procedure takes. The discipline and practice 
of law itself works through making distinctions and thereby categorising and systematising the world and the objects of legal inquiry. ${ }^{2}$

At the edge of what the legal discipline can fathom out we find situations and actions that fittingly go under the general heading of "exceptions." While the exception to the legal rule is an integrated part of legal reasoning in everyday life (a certain rule has a few exceptions, and these exceptions in turn might have further exceptions), the notion of the state of exception refers to a suspension of the legal order as such. The suspension of the normal legal activities and legally regulated procedures of public actors creates problems beyond just finding out (or arguing for) what rule applies to a given situation. ${ }^{3}$

The diverse phenomena and practices that go under headings like state of exception (or siege, catastrophe, etc), dictatorship, martial law, emergency legislation, sovereign prerogative, and martial law, all stretches the juridical ability to gather and grasp real life inside a juridical system of concepts and distinctions.

Let us therefore investigate two examples of theoretical typological reflection used in the legal literature on emergencies, crises and legal responses. ${ }^{4}$ While in many ways quite different, the almost contemporaneous ${ }^{5}$ publications of Agamben's State of exception in 2005 (Italian edition Lo stato di eccezione in 2003) and Oren Gross and Fionnuala Ní Aoláin's Law in Times of Crisis: Emergency powers in theory and practice in 2006 both explicitly respond to developments after 9/11 and the build-up of the war on terror. Both studies also

${ }^{2}$ I challenge anyone to find a proper counter-example. There might be lawyers of a certain aggressive disposition that use broad and vague exclamations as their method of arguing in court. And of course, we have all read court rulings without much distinctions or clear use of concepts. But when distinctions as such and arguments based concepts are left totally to the wayside, we hardly identify such utterances or practices as law. A couple examples from the anthropological literature: "stupefying multiplication of distinctions" (Latour 2010, 16) that "legalistic thought classifies and organizes" (Pirie 2013, 14) and "Law does far more than provide rules for conduct: it establishes a whole set of categories and relationships that define interactions between people, property, and other social entities" (Pirie 2013, 52).

${ }^{3}$ This also relates to other issues of distinctions, such as vagueness. See Endicott's (2000) Vagueness in law. Consider also: "Where it seems that the law cannot draw a boundary, it would seem impossible for a human being to identify one. Yet the law trains officials for that very purpose, and appoints them to judge and to regulate that which it leaves undetermined, as rightly as they can." Aristotle, Politics III.16

${ }^{4}$ There of course exist others, e.g., Ferejohn and Pasquino 2004; Dyzenhaus 2006; Lazar 2009. An empirical study was the basis for the Venice Commission report (1995). Seminal works are Rossiter 1948 and Schmitt [1932] 2004. An interesting Swedish study is Tingsten (1930, French translation 1934).

${ }^{5}$ It can be noted that Gross and Ní Aioláin refers to Agamben's book in three places (page 50 citing a formulation about necessity being the first and original source of law, page 170 at the final sentence in chapter 3 in relation to Schmitt, and at page 240 when discussing the Roman senatus consultum ultimum). Their study must have been almost finished when Agamben's book appeared (and quickly gained notoriety) in English in 2005. While they implicitly acknowledge the relevance of Agamben they do not engage in any discussion of his theoretical and historical inquiry or claims. 
put these contemporary developments in their medium and long-term historical perspective (both reaching back through modernity and all the way to antiquity).

While Agamben's book approaches the issue from the discipline of philosophy and Gross and Ní Aiolaín from the legal field, they meet in a field where legal, historical, philosophical and political reflection must come to bear on the problem. This also means that they engage with a similar set of legal theoretical concepts.

\section{TYPOLOGICAL ATTEMPTS WITH GROSS AND NÍ AIOLAÍN}

One of the main arguments in Gross and Ní Aiolaín's book is that there is a shared fundamental assumption of all models of emergency regimes. They call this the "assumption of separation" which is "the belief in our ability to separate emergencies and crises from normalcy, counter-terrorism measures from ordinary legal rules and norms" (Gross, Ní Aoláin 2006, 171). Their argument is more or less that this assumption must be abandoned: 6

However, as we demonstrate below, bright-line distinctions between normalcy and emergency are frequently untenable. In various meaningful ways, the exception has merged with the rule, and "[e]mergency government has become the norm." (Gross, Ní Aoláin 2006, 171)

Despite this the authors produce a typology that systematically distinguishes between different legal regimes and crisis responses. The untenability of "brightline distinctions" does not stop them from taking responsibility for making such distinctions for the purposes of their study.

Gross and Ní Aoláin present us with a systematic typology of different models of emergency regimes. These are different responses to the conflict between democracy and democratic ideals (individual rights, legitimacy, accountability and rule of law) on the one hand and the call for "exercise of unfettered discretion and practically unlimited powers" on the other (Gross, Ní Aoláin 2006, 9). The authors' models are both theoretical and based on empirical examples (actual actions by different actors historically and rationalizations of these actions). The aim is ambitious: "Indeed we argue that these theoretical frameworks are applicable across legal systems and provide an equally relevant conceptual framework to assess international legal responses to crisis" (Gross, Ní Aoláin 2006, 9).

Three main types of models are presented, with respective subtypes. The first - Models of accommodation - is based on a discourse of democratic societies that accommodates the pressures an emergency puts on the state through relaxation by loosening or suspending legal or constitutional structures, but still attempting to maintain "normal legal principles and rules as much as possible" (Gross, Ní Aioláin 2006, 17). This loosening or suspension of the normal structures can

\footnotetext{
${ }^{6}$ A similar critique (with reference to Gross and Ní Aoláin) is made by Loevy $(2016,5)$.
} 
be done in different ways, either in a predetermined fashion or on an ad hoc basis. The amount of suspension or relaxation differs, as well as the way in which it is structured, e.g., whether new competencies are defined inside legal or constitutional rules (as in emergency provision or special emergency legislation) or if the competency is broad and far-reaching, but limited in time (Roman dictatorship) or geographical scope (martial law). The headings under which the authors discuss these types of models are (Gross, Ní Aioláin 2006, chapter 1):

- Classical models of accommodation

- Roman dictatorship

- French "state of siege"

- Martial law in the United Kingdom

- Constitutional accommodation

- Emergency provisions in constitutional documents

- Constitutional necessity

- Declaration of state of emergency (or similar)

- Legislative accommodation

- Modifying ordinary laws

- Special emergency legislation

- Interpretative accommodation

- "Each crisis brings its word and deed" (combinations of the above).

The second type of models - Law for all seasons - begins with the premise that there is no special legal regime for emergencies or other threats (Gross, Ní Aioláin 2006, chapter 2). This is also called the "Business as Usual" model as it rejects accommodation and argues that "any particular emergency cannot excuse or justify a suspension, in whole or in part, of any existing piece of the ordinary legal system" (Gross, Ní Aioláin 2006, 86).

The third type of models - Models of extra-legality - assumes that emergencies challenge both of the previous models, and that the response must go beyond the legal altogether. The officials that have to act need to rely on the moral legitimation of their actions when they break or go beyond clear rules or competencies. They can argue that their actions are based on a sovereign prerogative that trumps the normal or written constitution, or they can hope for ex-post ratification of their necessary actions by a sympathetic legislator (Gross, Ní Aioláin 2006, chapter 3).

The above categories are not all necessarily mutually exclusive or distinct from each other. Not all historical examples fit nicely into one of the categories, and at times different interpretations (or rationalizations) would put them in different categories than the ones Gross and Ní Aoláin have done. They also discuss arguments and critiques than can be levied against all models and theories that they present. These form the bulk of the rest of the book. They also discuss theories that are seen by others as distinct but that they categorise in one of the 
existing categories (e.g. the section on Carl Schmitt, whose theory they see as an example of constitutional necessity).

The conclusions of Gross and Ní Aoláin's study in relation to the question of typology is not clear. But in their introduction, they summarize their position in a warning against "blind adherence" to the different emergency regimes models that "may result in long-term destabilization" of the rule of law and rights protection (Gross, Ní Aioláin 2006, 12). They apparently see a danger in strict adherence to distinctions and concepts. Nonetheless, they seem not to have lost all hope, at least as long as jurists can continue their work. In an understated formulation they conclude: "Innovative legal concepts to deal with the problem of emergencies may be needed" (Gross, Ní Aoláin 2006, 12).

\section{TYPOLOGICAL PROBLEMS WITH AGAMBEN}

In a different philosophical and critical vein Giorgio Agamben's State of Exception starts out with lamenting that even though Carl Schmitt established the "essential contiguity between the state of exception and sovereignty" already in 1922, the public law jurists (for whom the concept of sovereignty is central) have not yet produced a theory of the state of exception in public law. ${ }^{7}$ While some "regard the problem more as a quaestio facti than as a genuine juridical problem", others want to place the state of exception on the limit between politics and law, or even outside of law or the juridical altogether (Agamben 2005, 1). In other words, while the state of exception must be a problem and object of inquiry for public law, public law seems to either disavow it or not being able to actually grasp it.

Agamben has a primary purpose with his study. It is to investigate this "noman's land between public law and political fact, and between the juridical order and life" (Agamben 2005, 1). By uncovering the ambiguous zone between "the difference - or the supposed difference - between the political and the juridical, and between law and the living being" he wishes to answer the question of "what does it mean to act politically?" (Agamben 2005, 2). This final question, situated on a politico-ontological level, is to be approached through the study of the public law problem of the state of exception, as a special case of the general relation between law and life. ${ }^{8}$ Agamben argues that the path leading to this general

${ }^{7}$ Here Agamben cannot be read as saying that no attempts have been made. Several such theories are presented in the book, and he explicitly writes that the "most rigorous attempt to construct a theory of the state of exception" was made by Carl Schmitt in the 1920s. I interpret Agamben as arguing that no attempt so far has proved satisfactory, rather than that public law has ignored the issue.

${ }^{8}$ This central aspect of his theory is discussed several times throughout the book (and also in the broader project of his Homo Sacer series), e.g., as "[b]eing-outside, and yet belonging" (Agamben 2005, 35). 
problem requires as a "preliminary condition" a theory of the state of exception (Agamben 2005, 1).

So, a legal theory of the state of exception not only can and should be supplied for the discipline of public law as such, but has a wider relevance. It might even contain a key to politico-ontological questions of the highest order. In what way does Agamben proceed then? While he does not produce a typology as such, he extensively discusses several different types of legal theories, legal arguments concerning the categorisation of and response to crises or perceived emergencies. ${ }^{9}$ We can tentatively outline the concepts or terms he discusses, even though the discussion is not strictly ordered as such in the book: the concepts state of exception (Ausnahmezustand), state of necessity/emergency (Notstand), state of siege (état de siège, political state of siege [état de siège politique] and fictitious [état de siège fictif]), emergency powers, martial law, full powers (pleins pouvoirs, plenitudo potestatis); dictums such as necessitas legem non habet/Not kennt kein Gebot; the doctrine of constitutional dictatorship; legal forms of norm-making activity such as emergency decrees; as well as the phenomena of civil war (iustitium).

The above concepts cannot easily be ordered (as in a systematic typology), since they are used to describe both perceived situations and responses to them. For some authors they are also synonyms, while others make clear distinctions between them. Agamben himself uses "the syntagma state of exception as the technical term for the consistent set of legal phenomena that [the present study] seeks to define" (Agamben 2005, 4); in other words, he encompasses all the above under the phrase and subsequent theory of the state of exception. All the different concepts and terms point towards a "consistent set of legal phenomena", and the ultimate goal of the discussion is to show not only the underlying similarity, but rather the more foundational nature of law as always containing a threshold and a limit which shows itself in concrete cases of states of exceptions.

Agamben's central theoretical point is that the state of exception today has reached a new level of "maximum worldwide deployment" (Agamben 2005, 87). This means that although laws are often applied as we would expect, the "normative aspect of law can [...] be obliterated and contradicted with impunity by a governmental violence" that produces a "permanent state of exception" while still claiming to apply the law (Agamben 2005, 87).

The end point of Agamben's theory in State of exception is therefore that all the previous categories and distinctions essentially break down. To contain the state of exception "within its spatially and temporally defined boundaries in order to then reaffirm the primacy of a norm and of rights" is not possible, because the state of exception as such is the basis for all application of law. This means that

${ }^{9}$ One of his main points is that there is uncertainty both conceptually and terminologically: "The uncertainty of the concept is exactly matched by terminological uncertainty. The present study will use the syntagma state of exception as the technical term for the consistent set of legal phenomena that it seeks to define" (Agamben 2005, 4). 
we cannot return to a "state of law" (Agamben 2005, 87) because the dialectic of "anomie and nomos, [...] life and law, [...] auctoritas and potestas" (Agamben $2005,86)$ has broken down. They are no longer "conceptually, temporally, and subjectively distinct" as they once were.

Since the state of exception "becomes the rule" (Agamben 2005, 86), in other words it has become the new normality, the question arises what use we have of the typologies? In a sense Agamben's study is a typological inquiry that deconstructs and argues for, if not the uselessness, then at least the ultimate futility of typologies.

I read Agamben's argument as saying two things at the same time: 1) there are no ultimate distinctions to be made between the different categories of emergency regimes, definitions of crises and their responses, since the era we now live in no longer respects such distinctions; 2) but at the same time, we must (like Agamben does) still engage with these categories, concepts and typologies, at least for the purposes of removing the veil that cover the violence and exercise of power without normative restrictions that actually takes place.

I am not sure if we should read Agamben as saying (or at least not sure I want to follow him if he does say) that we cannot sustain any hope for legal regulation, or that engaging in the juridical distinctions amounts to sophistry or naïveté. In specific situations and contexts, arguing for the norm-boundedness of state action, insisting on the distinction between emergency and normality, or taking flawed or dishonest legal arguments to task, is still an important task for the jurist. She might not harbour high hopes for (re)construction of legal regimes properly distinguishing between normality and emergency. While she should be wary of assuming such a separation (Gross, Ní Aioláin), she can still insist on the need for legal distinctions and continue the task of critiquing and developing legal arguments concerning emergency regimes and crisis responses. ${ }^{10}$

\section{LEVELS OF ANALYSIS}

It becomes in the end a question of on what level the analysis should be done. Several levels of description and distinctions of emergencies and legal categorisation of responses can be identified:

1. explicit descriptions of actions by actors themselves (what words or concepts are referred to by the actors),

2. positivist legal categories available in the context (what concepts and distinctions are used in the legal order where the actions take place),

${ }^{10}$ This is also what we have seen Agamben himself doing, not only as a philosopher in this and other books, but also as a public intellectual criticising specific exceptional regimes that are being normalized. One example is his refusal to travel to the US due to its biopolitical techniques of border control (Agamben 2004). 
3. meta/comparative categories (concepts and distinctions available in literature, theoretical and comparative, e.g., as in Gross and Ní Aoláin),

4. philosophical/ontological concepts and categories that question or inquire into all the previous categories (e.g., Agamben's thesis of the "permanent state of exception").

What is the interrelation between these different levels of analysis? One way of reading them is that there is a continuous and rising convergence the higher one gets in the hierarchy of analysis. Level 1 (explicit descriptions by actors themselves) might vary and probably often lack a specificity and consistency - it might be unclear what such descriptions actually refer to, and actors without legal training might muddle the terminology and concepts used. Levels 2-4 are hierarchically ordered and reach towards a convergence, or ultimate distinctions. This might end up in a basic distinction between a normal situation and an exceptional situation ${ }^{11}$ or in a monistic argument as in Agamben's thesis of a permanent state of exception, where all such distinctions ultimately meld together or vanish.

This is not to argue that one level should prevail on the expense of the others. Important practical and academic work can be done in relation to every level, and relating to several levels simultaneously. Related to this is Agamben's argument that two opposing forces interact in the legal history of the West:

The juridical system of the West appears as a double structure, formed by two heterogeneous yet coordinated elements: one that is normative and juridical in the strict sense (which we can for convenience inscribe under the rubric potestas) and one that is anomic and metajuridical (which we can call by the name auctoritas) (Agamben 2005, 85f).

Agamben argues that as long as these two aspects can "remain correlated yet conceptually, temporally, and subjectively distinct" the dialectic "though founded on a fiction - can nevertheless function in some way" (Agamben 2005, 86). When they "coincide in a single person, when the state of exception, in which they are bound and blurred together, becomes the rule, then the juridico-political system transforms itself into a killing machine" (Agamben 2005, 86), in other words: when a fascist state arises with a Führer or a Duce, or when democracies no longer respect, or rather uphold, the difference between normality and emergency, unbound violence beckons. This relates directly to the critique by Gross and Ní Aioláin's argument that we should not accept the "assumption of separation" and "bright-line distinctions between normalcy and emergency are frequently untenable" which means that "[i]n various meaningful ways, the exception has merged with the rule" (Gross, Ní Aiolaín 2006, 171). Where do these dire analyses and predictions lead us in regard to typologies? Can the typologies survive and retain usefulness when "the exception has merged with the rule" (Gross, Ní Aoláin) or "the state of exception has become the rule" (Agamben)?

${ }^{11}$ This dichotomy, used not least by Carl Schmitt, has a long tradition, cf. Gross 1999, 1834ff. 


\section{CONCLUSIONS}

This might be the very moment when systematic inquiry and sophisticated distinctions are necessary more than ever. To develop typologies and attempt at all times to uphold the difference between emergency and normality - is that the task the responsible jurist must engage in when facing the breakdown of those very categories? ${ }^{12}$

The answer will probably differ depending on the specific circumstances and paths available. But my wager is that the jurist cannot escape distinctions, definitions and therefore explicit or implicit typologies. If we are to play any role, these are the tools we are given and the tools we can use. Leaving them behind means abandoning the discipline and practice of law. That might be advisable or necessary on an individual level. ${ }^{13}$ But it means no longer acting as a jurist.

On the other hand, this, as I have already implied above, does not mean that all typological activity is the same. Depending on the aim of an intervention or a study, and the adherence or loyalty to a certain role (such as advocate, judge, legal scholar, philosopher) the use of typologies will differ. As a legally trained activist or politician, as a member of a legislative preparatory committee, as a judge or ombudsman, or as a law professor - all these roles, depending on the goal, can, to varying degrees, employ different levels of analysis. In making explicit descriptions as an activist or a politician on level 1, may also use legal terminology borrowed from the other levels. Or using positivist legal categories, as a judge, on level 2. Comparative categories can be used in the legislative preparatory process by a committee member on level 3. And finally philosophical/ ontological concepts may be applied by a law professor acting on level 4 .

But again - these are not neatly divided configurations. The legal scholar needs to engage regularly with all four levels (or otherwise risk becoming irrelevant for the legal discipline) and there is nothing stopping politicians or judges from doing the same. This even though in practice the perceived role and loyalty constrains such eclecticism - just as the positivist tradition often constrains legal scholars to stay firmly inside the doctrinal level 2 engagement with familiar legal concepts and logic.

An important benefit of being aware of and using these levels of analysis is that it lowers the risk of muddling concepts from different levels. A clear example of this is the widespread discussion of "states of exception" in the current debate on both the climate crisis and the COVID-19 pandemic. Whether different authors refer to positivist/legal categories or e.g. factual events is often not very clear. Here further analytic distinctions are of great value.

${ }^{12}$ Agamben explicitly rejects this possibility (Agamben 2005, 87).

${ }^{13}$ Or perhaps collectively in a future where law and legal activity as such is suspended or abolished. 
In conclusion, we are bound to stay with distinctions, definitions and typologies. But we can go beyond the typologies of legal concepts, and use a meta-level typology, as has here been tentatively suggested, to grasp the issue on an epistemological level. In this way we can retain a critical and self-reflective distance towards a practice that we cannot leave, and even use it critically against itself.

\section{BIBLIOGRAPHY}

Agamben, Giorgio. 2004. "No to bio-political tattooing." Le Monde, January 10, 2004.

Agamben, Giorgio. 2005. State of exception. Chicago: University of Chicago Press. https://doi. org/10.2307/j.ctv1134d6w.16

Dyzenhaus, David. 1997. Legality and legitimacy: Carl Schmitt, Hans Kelsen, and Hermann Heller in Weimar. Oxford: Clarendon Press.

Dyzenhaus, David. 2006. The constitution of law: Legality in a time of emergency. Cambridge: Cambridge University Press. https://doi.org/10.1017/CBO9780511618246

Ferejohn, John. Pasquale Pasquino. 2004. "The law of the exception: A typology of emergency powers." International Journal of Constitutional Law 2(2): 210-239. https://doi.org/10.1093/ icon/2.2.210

Gross, Oren. 1999. "The Normless and Exceptionless Exception: Carl Schmitt's Theory of Emergency Powers and the Norm-Exception Dichotomy." Cardozo Law Review 21: 18251868 .

Gross, Oren. Fionnuala Ní Aoláin. 2006. Law in times of crisis: emergency powers in theory and practice. Cambridge: Cambridge University Press. https://doi.org/10.1017/ CBO9780511493997

Latour, Bruno. 2010. The making of law: an ethnography of the Conseil d'Etat. Cambridge: Polity.

Lazar, Nomi Claire. 2009. States of Emergency in Liberal Democracies. Cambridge: Cambridge University Press. https://doi.org/10.1017/CBO9780511596704

Loevy, Karin. 2016. Emergencies in public law: the legal politics of containment. New York: Cambridge University Press. https://doi.org/10.1017/CBO9781316403556

Pirie, Fernanda. 2013. The anthropology of law. Oxford: Oxford University Press.

Rossiter, Clinton. 1948. Constitutional dictatorship. Princeton: Princeton University Press.

Schmitt, Carl. 2004. Legality and legitimacy. Duke University Press. https://doi.org/10.1215/9780 822385769

Tingsten, Herbert. 1930. Regeringsmaktens expansion under och efter världskriget: studier över konstitutionell fullmaktslagstiftning. Lund: Gleerup.

Tingsten, Herbert. 1934. Les pleins pouvoirs: l'expansion des pouvoirs gouvernementaux pendant et après la grande guerre. Paris: Librairie Stock.

Venice Commission. 1995. Emergency Powers - Science and technique of democracy No. 12. Strasbourg: Council of Europe. https://www.venice.coe.int/webforms/documents/?pdf=CDL -STD(1995)012-e 